\title{
PENGARUH VARIASI SUHU PERENDAMAN TERHADAP KAREKTERISTIK PATI TERMODIFIKASI DARI KULIT SINGKONG DENGAN SUBTITUSI SARI KEDELAI
}

\author{
Lusi Marlina $^{1}$, Cengristitama ${ }^{1}$ \\ ${ }^{1}$ Teknik Kimia, Politeknik TEDC Bandung, \\ Jl. Politeknik-Pesantren Km 2 Cibabat Cimahi Utara, Cimahi, 40513, Indonesia \\ Email : lusi@poltekdc.ac.id
}

\begin{abstract}
Abstrak
Produksi dan konsumsi singkong di Indonesia setiap tahunnya terus meningkat, dimana limbah pengupasan singkong yang diperoleh berupa kulit juga semakin banyak. Dalam upaya mengurangi limbah tersebut maka perlu adanya berbagai macam pengolahan. Salah satunya dengan mengolahnya menjadi tepung termodifikasi. Pelaksanaan penelitian dilakukan untuk mengamati "Pengaruh Variasi Suhu Perendaman Terhadap Kareketeristik Pati Termodifikasi dari Kulit Singkong dengan Subtitusi Sari Kedelai”. Perlakuan penelitian menggunakan metode eksperimental yang dilakukan di laboratorium, dimana secara garis besar tahapan penelitian yang dilakukan ditunjukkan pada bagan rancangan penelitian seperti yang disajikan berikut ini variasi perendaman yang digunakan berupa berupa suhu perendaman dan konsentrasi starter Bimo-CF. Perlakuan perendaman dengan temperatur (suhu) air $50{ }^{\circ} \mathrm{C}$ dan $60{ }^{\circ} \mathrm{C}$, sedangkan konsentrasi starter Bimo-CF yang digunakan yaitu $1,0 \% \mathrm{w}$ dan $2,5 \% \mathrm{w}$. Bahan baku didapat untuk penelitian ini diperoleh dari kulit singkong segar langsung dari pedagang di pasar Antri Cimahi, di sortir, diambil kulit yang baik, dibersihkan, dicuci dan dipotong-potong menjadi irisan (sawut) atau chip dengan ketebalan 1,5-2,0 mm, garam dapur merk Refina dengan kandungan $\mathrm{NaCl} 99,25 \%$, Starter Bimo-CF yang mengandung bahan aktif berbagai mikroba bakteri asam laktat, yang didapat dari "Balai Besar Penelitian dan Pengembangan Pasca Panen Pertanian" di Bogor, sedangkan susu kedelai yang diperoleh dari pedagang di pasar antri Cimahi. Pati/tepung kulit singkong termodifikasi yang sudah jadi di substitusi dengan sari kedelai agar kandungan protein pada tepung dapat meningkat. Berdasarkan hasil uji analisa berupa uji (water level), (ash level), (protein level), derajat putih dan uji organoleptik diperoleh perlakuan terbaik yaitu pada tepung kulit singkong pada variasi perendaman dengan suhu $50^{\circ} \mathrm{C}$ dan konsentrasi starter sebanyak 1,0\%. Dengan kadar air sebesar 2,00\%, kadar abu 1,94\%, kadar protein 2,52\%, kadar HCN 35,3928 mg/kg dan derajat putih sebesar 67,02\% yang sudah sesuai dengan SNI 01-2997-1992.
\end{abstract}

Keywords: cassava skin, bimo-cf, flour, fermentation, soy essence

\section{Pendahuluan}

Hasil olahan pangan berbahan dasar singkong seperti getuk, tape, awu, combro, gaplek, tapioka, dan tape, dari proses pengupasannya banyak limbah yang dihasilkan berupa kulit singkong. Persentase kulit singkong bagian luar berkisar $0,5 \%-2 \%$ berat total singkongnya sementara kulit singkong bagian dalam berkisar 8\%-15\%. Limbah yang diperoleh dari pengupasan singkong ini merupakan kategori sampah organik/mudah terdegradasi (membusuk/ hancur) secara alami. Jumlah produksi dan konsumsi singkong di Indonesia setiap tahunnya terus meningkat, dimana limbah hasil pengupasan singkong yang diperoleh juga semakin banyak. Menurut B. Sudaryanto (1989), "kandungan nutrisi kulit singkong adalah Bahan kulit kering 17,45 gram, Protein 8,11 gram, Pektin 0,22 gram, Serat kasar 15,20 gram dan Lemak 0,63 gram". Untuk mengurangi limbah tersebut maka perlu adanya berbagai macam pengolahan. Salah satunya dengan mengolahnya menjadi tepung untuk keperluan pangan. Tepung/Pati termodifikasi merupakan pati dengan gugus hidroksi yang telah diubah melalui suatu reaksi kimia baik melalui reaksi oksidasi, esterifikasi, maupun reaksi sterifikasi atau dengan memanfaatkan struktur asalnya. Menurut Reilly (1985) "untuk mendapatkan sifat pati yang lebih baik, maka pati diberi beberapa perlakuan seperti penggunaan panas, asam alkali, zat pengoksidasi atau bahan kimia lainnya yang nantinya akan menghasilkan gugus kimia baru atau perubahan bentuk, ukuran serta struktur molekul pati”. Pati termodifikasi dapat berfungsi sebagai bahan pengental, pemantap, pengisi dan pengemulsi bagi makanan. Perubahan sifat pada pati menandai bahwa pati tersebut telah mengalami modifikasi sehingga mudah diaplikasikan sesuai kebutuhan. Dalam pengolahan tepung termodifikasi dari kulit singkong tentunya terdapat faktor-faktor yang mempengaruhi karateristik dari tepung tersebut yaitu seperti suhu perendaman dan karakteristik starter yang digunakan pada saat perendaman. Proses perendaman dilakukan dengan dua tahap, tahap pertama perendaman menggunakan larutan $\mathrm{NaCl}$ dan tahap kedua perendaman dengan 
menggunakan starter Bimo-CF. Perendaman juga ini untuk menjaga warna kulit singkong tidak mengalami browning (kecoklatan) dan mampu banyak mengurangi kadungan asam sianida $(\mathrm{HCN})$. Dari uraian-uraian di atas, maka dilakukan penelitian dengan tujuan untuk mengetahui pengaruh perendaman garam terhadap berat tepung kulit singkong hasil fermentasi dengan menggunakan beberapa jenis ragi. Sampah atau limbah kulit singkong merupakan hasil pengupasan bahan baku dari pengolahan gaplek, tepung singkong, getuk, tape, dan makanan dengan bahan baku singkong lainnya. Kuantiti kulit singkong di tanah air kita ini cukup berlimpah, sejalan dengan kemampuan negara kita ini merupakan penghasil singkong terbesar di dunia, dan terus mengalami kenaikan produksi setiap tahunnya. Kulit singkong ini juga mengandung karbohidrat yang tinggi sehingga layak dikonsumsi bagi manusia. Berlebihnya kulit hasil pengupasan singkong ini, misalnya kulit luarnya kurang lebih $2 \%$ dari berat total kulit singkong dan kulit bagian dalam berkisar $18 \%$ 19,5\%. Peranan kulit singkong selama ini, kurang diperhitungan karena dianggap hanya limbah yang tidak atau kurang manfaatnya, dan kulit singkong mengandung asam sianida, dengan kadar glukosida sianogenik pada kulit umbi mencapai $>5$ kali lebih besar dari umbinya. Sifat racun pada singkong (termasuk kulit umbi). Karena terbebasnya HCN dari kandungan glukosida sianogenik. Kadar total sianida yang terdapat pada kulit singkong sebesar $150 \mathrm{mg}$ sampai $360 \mathrm{mg}$ HCN per $\mathrm{kg}$ berat segar. Kandungan sianida yang terdapat pada kulit singkong ini bervariasi dan terdapat juga varietas tanaman singkongnya.

Dengan melakukan sedikit proses pengurangan terhadap racun tersebut dalam proses produksi tepung kulit singkong (tepung mokus) diharapkan menjadi aman untuk di konsumsi.

\section{Bahan dan Metode Penelitian}

\section{Desain Penelitian}

Perlakuan penelitian menggunakan metode eksperimental yang dilakukan di laboratorium, dimana secara garis besar tahapan penelitian yang dilakukan ditunjukkan pada bagan rancangan penelitian seperti yang disajikan dalam bentuk desain penelitian yang terlihat pada gambar 1 . berikut ini :

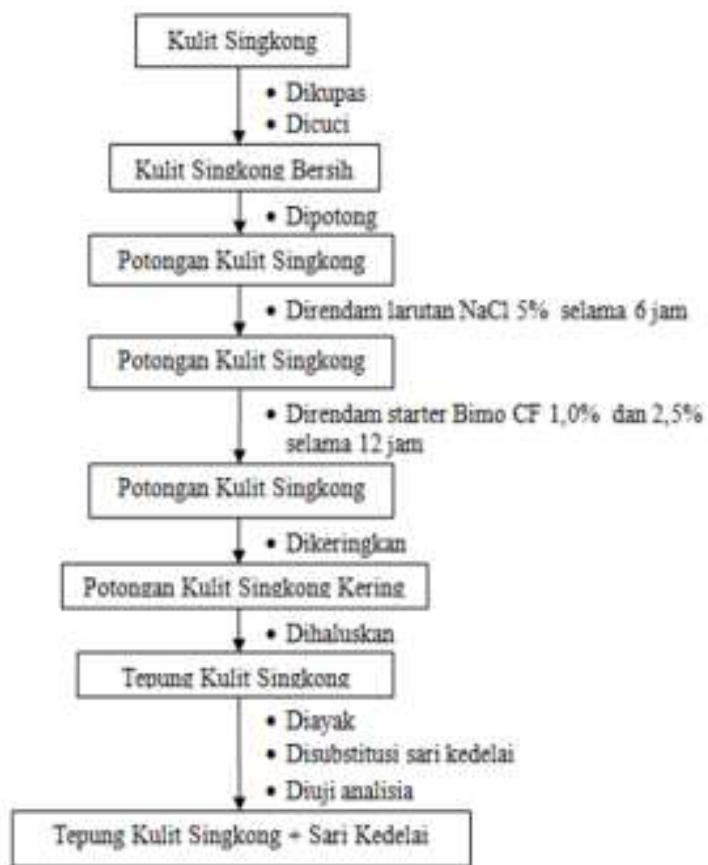

Gambar 1. Diagram Alir Pembuatan Tepung Kulit Singkong

\begin{abstract}
Alat dan Bahan
Peralatan yang digunakan pada penelitian ini yaitu pisau, talenan, blender, pengayak, neraca, analitik, termometer, cawan porselen, gelas kimia, desikator, tanur, oven, hot plate, baskom dan nampan. Bahan yang digunakan pada penelitian ini yaitu kulit singkong sebanyak 5 kilogram, garam, starter dan sari kedelai. Kulit singkong disini didapatkan dari pedagang singkong keju sekitar Kota Cimahi.
\end{abstract}

\section{Prosedur Penelitian}

Tahap-tahap pada penelitian ini yaitu kulit singkong sebanyak 5 kilogram dikupas seluruh kulit luarnya yang masih menempel pada kulit bagian kulit dalam. Kulit singkong yang sudah dikupas kemudian dicuci dengan menggunakan air yang mengalir sampai bersih. Setelah itu kulit singkong dipotong kecil-kecil agar dapat mempercepat saat proses pengeringan nantinya. Kemudian kulit singkong direndam.

Terdapat dua tahap perendaman, yang pertama perendaman dengan menggunakan larutan garam sebanyak $5 \%$ dengan lama perendaman yang digunakan yaitu selama 6 jam sedangkan perendaman yang kedua menggunakan Starter Bimo CF dengan variasi konsentrasi $1,0 \% \mathrm{w}$ dan $2,5 \% \mathrm{w}$ dan lama perendaman yang digunakan selama 12 jam. Variasi suhu yang digunakan pada dua perlakuan perendaman tersebut yaitu $50^{\circ} \mathrm{C}$ dan $60^{\circ} \mathrm{C}$, dengan tujuan untuk mengetahui suhu terbaik manakah yang dapat mempengaruhi karakteristik dari tepung kulit singkong. Kulit singkong yang sudah direndam kemudian dikeringkan dengan menggunakan alat oven hingga mencapai bobot konstan. Setelah mendapatkan bobot konstan, kulit 
singkong dihaluskan menggunakan blender hingga menjadi tepung. Lalu tepung kulit singkong tersebut diayak agar didapatkan ukuran yang seragam. Setelah itu, tepung kulit singkong yang sudah diayak lalu disubstitusi dengan sari kedelai dengan perbandingan $1: 1$, tujuan dilakukanya hal ini karena kebanyakan tepung modifikasi dari kulit singkong memiliki kandungan protein yang rendah jika dibandingkan dengan tepung lainnya, sedangkan sari kedelai sendiri merupakan olahan yang mempunyai kandungan protein yang tinggi, oleh karena itu tepung kulit singkong disini dicampur dengan sari kedelai dengan harapan dapat menaikan kadar protein dari tepung kulit singkong itu sendiri. Tepung kulit singkong yang sudah disubstitusi dengan sari kedelai kemudian dilakukan uji analisa berupa uji kadar air, kadar abu, kadar protein, kadar HCN, derajat putih dan uji organoleptik.

\section{Hasil dan Pembahasan}

Hasil analisa tepung kulit singkong termodifikasi setelah disubtitusi adalah sebagai berikut:

\section{Kadar Air}

Pada gambar 2. di bawah ini terlihat bahwa kadar air terendah ditunjukkan pada sampel $50^{\circ} \mathrm{C} 1.0 \%$ dan kadar air tertinggi diperoleh dari dua sampel yaitu sampel $50^{\circ} \mathrm{C} 2.5 \%$ dan sampel $60{ }^{\circ} \mathrm{C} 2.5 \%$. Semakin rendah suhu dan konsentrasi starter yang digunakan saat perendaman maka kadar air yang dihasilkan akan rendah juga, sebaliknya semakin tinggi suhu dan dan konsentrasi starter maka kadar air yang dihasilkan akan tinggi juga.

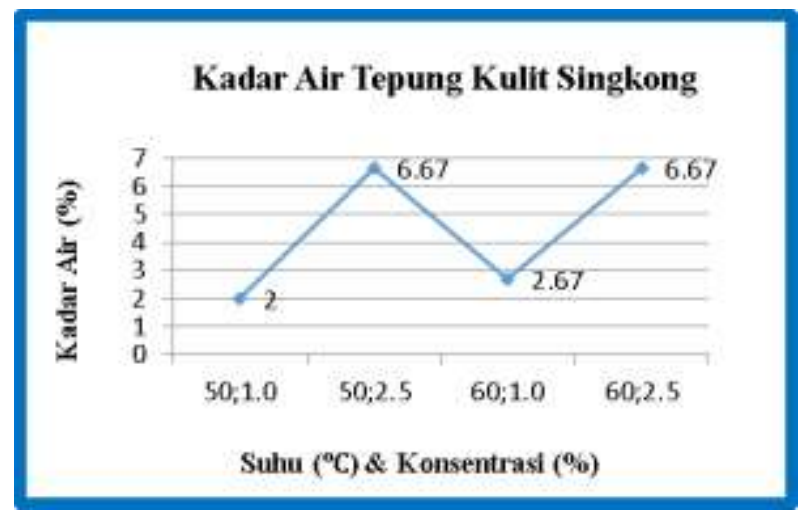

Gambar 2. Pengaruh Suhu \& Konsentrasi Perendaman terhadap Kadar Air Tepung Kulit Singkong

Berdasarkan SNI 01-2997-1992 kadar air pada keempat sampel tepung kulit singkong yang telah disubstitusi sari kedelai ini sudah memenuhi standar, dimana standar yang harus dipenuhi yaitu maksimal $12 \%$.

\section{Kadar Air}

Kadar abu merupakan campuran dari komponen anorganik atau mineral yang terdapat pada suatu bahan pangan. Jumlah mineral dalam suatu bahan pangan dapat ditentukan oleh kadar abu. Pada gambar 3. di bawah ini terlihat Kadar abu tertinggi terdapat pada sampel 500C $1.0 \%$ dan kadar abu terendah terdapat pada sampel 500C 2.5\%. Semakin tinggi konsentrasi starter yang digunakan maka akan makin sedikit kadar abu yang dihasilkan, sebaliknya semakin rendah konsentrasi starter maka semakin banyak kadar abu yang dihasilkan.

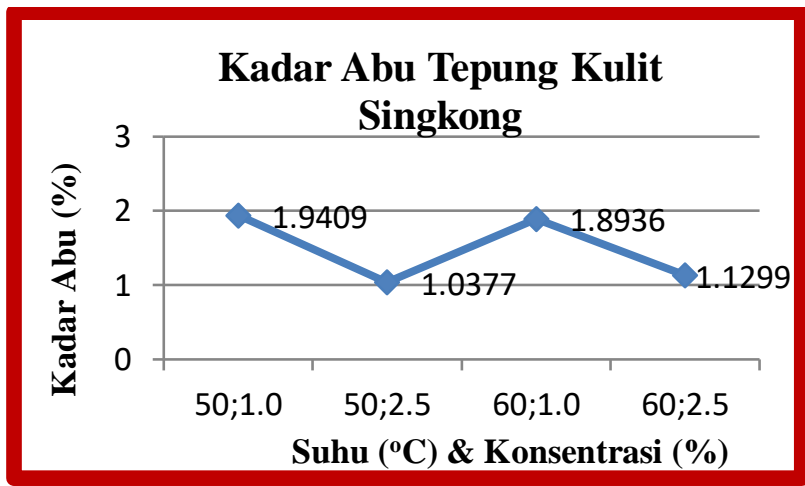

Gambar 3. Pengaruh Suhu dan Konsentrasi Peren-daman terhadap Kadar Abu Tepung Kulit Singkong

Hasil kadar abu pada sampel $50^{\circ} \mathrm{C} 1,0 \%$ dan sampel $60^{\circ} \mathrm{C} 2,5 \%$ sudah memenuhi SNI 01-2997-1992.

\section{Kadar Protein}

Analisis kadar protein tepung kulit singkong disini menggunakan analisi kualitatif metode Kjeldahl. Kadar protein, seperti ditunjukan pada gambar 4. Di bawah ini menunjukan kadar protein tepung kulit singkong tertinggi ditunjukkan pada sampel $50{ }^{\circ} \mathrm{C} 2.5 \%$ dan kadar protein terendah pada sampel $60{ }^{\circ} \mathrm{C} 1.0 \%$. Semakin rendah suhu dan tinggi konsentrasi perendaman yang digunakan, maka akan semakin banyak kadar protein yang terkandung dalam tepung kulit singkong.

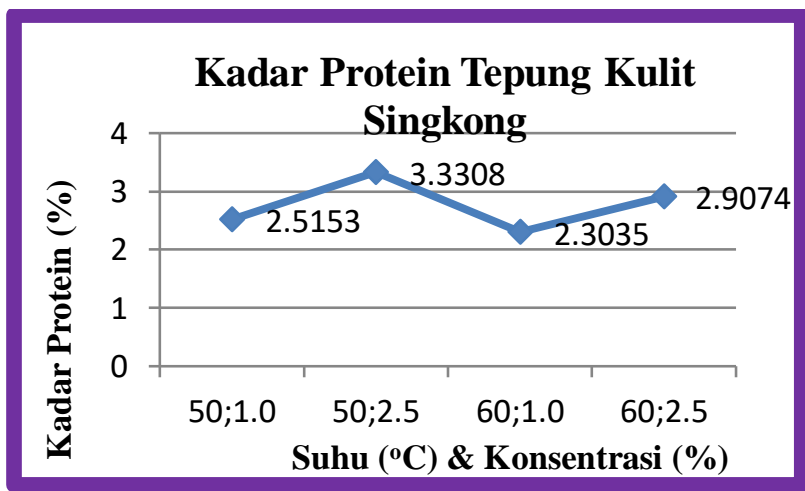

Gambar 4. Pengaruh Suhu dan Konsentrasi Peren-daman terhadap Kadar Protein Tepung Kulit Singkong

Kadar protein keempat sampel pada penelitian ini sudah memenuhi standar, dimana standar kadar protein yang harus dipenuhi yaitu 1,5\%-3,7\%. 


\section{Kadar HCN}

HCN dikenal sebagai racun yang mematikan Oleh karena itu kadar HCN pada suatu bahan pangan perlu diperhatikan, pada gambar 5 menunjukkan uji dari Kadar $\mathrm{HCN}$ tertinggi ditunjukan pada sampel $50^{\circ} \mathrm{C}$ $1.0 \%$ dan kadar HCN terendah ditunjukan pada sampel $60{ }^{0} \mathrm{C} 2.5 \%$. Semakin rendah suhu dan konsentrasi perendaman yang digunakan maka semakin besar kadar HCN yang dihasilkan, oleh karena itu kadar HCN pada suatu bahan pangan perlu diperhatikan.

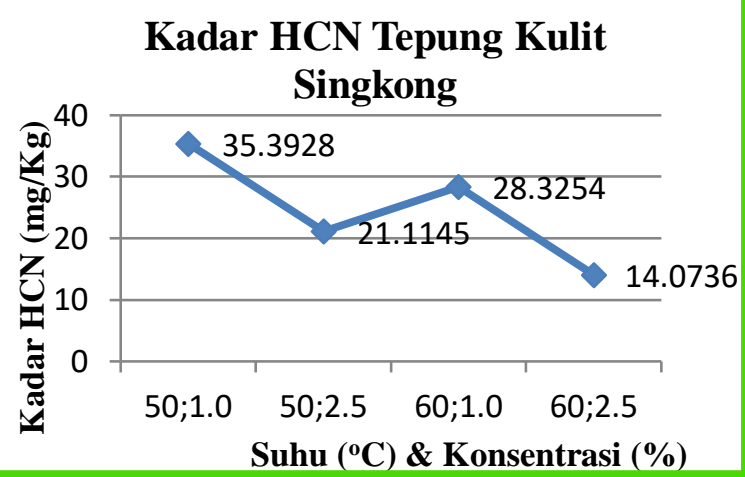

Gambar 5. Pengaruh Suhu dan Konsentrasi Peren-daman terhadap Kadar HCN Tepung Kulit Singkong

Berdasarkan SNI 01-2997-1992 kadar HCN pada keempat sampel tepung kulit singkong yang telah disubstitusi sari kedelai ini sudah memenuhi standar, dimana standar yang harus dipenuhi yaitu maksimal $40 \mathrm{mg} / \mathrm{kg}$.

\section{Derajat Putih}

Derajat putih merupakan tingkat keputihan suatu bahan yang erat kaitannya dengan mutu penerimaan konsumen. Secara umum, konsumen lebih menyukai bahan dengan warna yang cerah, maka dilakukanlah analisis derajat putih ini. Pada gambar 6 . nilai derajat putih tepung kulit singkong tertinggi ditunjukkan pada sampel $50^{\circ} \mathrm{C} 1.0 \%$ dan derajat putih terendah pada sampel $60^{\circ} \mathrm{C} 1.0 \%$. Semakin rendah suhu perendaman yang digunakan maka akan semakin besar derajat putih yang dihasilkan.

Perendaman dengan air dapat mencegah terjadinya pencoklatan enzimatis karena menghindari kontak dengan oksigen. Gambar 6 menunjukkan Pengaruh dari suhu perendaman yang digunakan. Semakin rendah suhu perendaman yang digunakan maka akan semakin besar derajat putih yang dihasilkan.

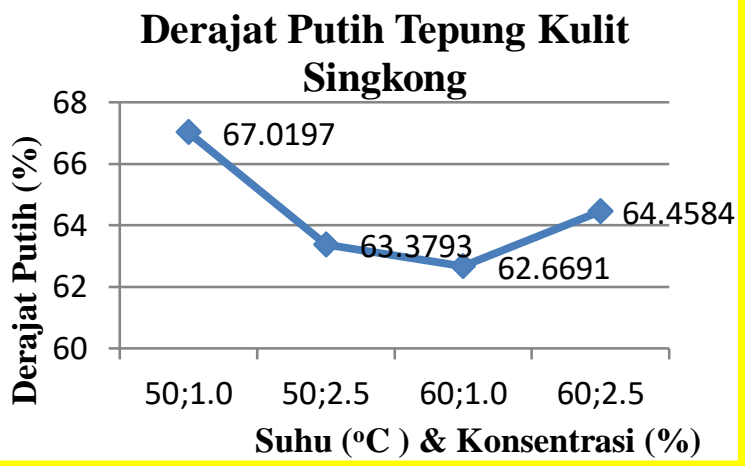

Gambar 6. Pengaruh Suhu dan Konsentrasi Peren-daman terhadap Derajat Putih Tepung Kulit Singkong

\section{Uji Orgoneleptik}

Penilaian organoleptik merupakan salah satu parameter penting untuk tingkat penerimaan panelis terhadap produk makanan yang diujikan. Uji orgaleptik dilakukan dengan menggunakan uji skoring yang meliputi pengujian warna, aroma, tekstur dan rasa, sedangkan untuk penerimaan keseluruhan atau kesukaan dilakukan dengan uji hedonik. Penjelasan gambar 7, grafik Hasil Uji Organoleptik Tepung Kulit Singkong berturut-turut adalah sebagai berikut: Nilai rata-rata warna tepung kulit singkong tertinggi terdapat pada sampel $60^{\circ} \mathrm{C} 1.0 \%$ yaitu 3.6 dengan warna Putih Kekuningan. Semakin rendah suhu dan tinggi konsentrasi maka warna yang dihasilkan akan mendekati warna putih. Nilai rata rata warna tepung terendah terdapat pada sampel $50^{\circ} \mathrm{C} 2.5 \%$ yaitu 2.6, dengan warna Kuning.

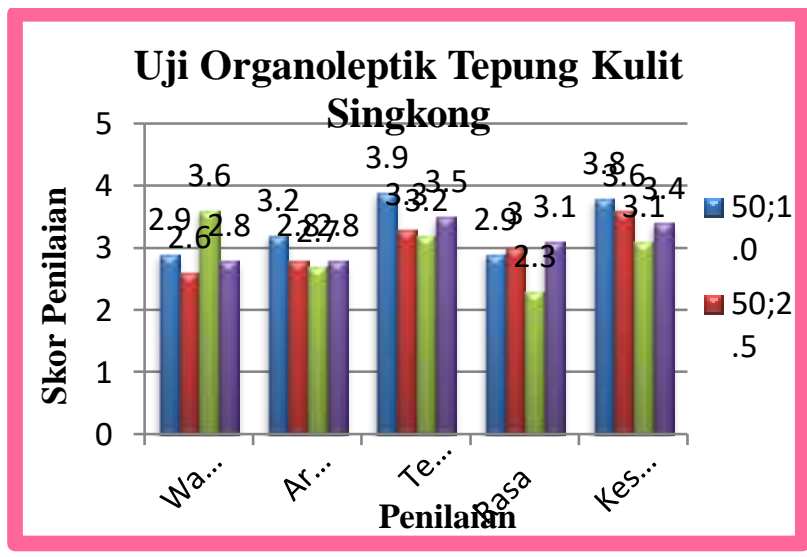

Selanjutanya Nilai rata-rata aroma tepung kulit singkong tertinggi terdapat pada sampel $50^{\circ} \mathrm{C} \quad 1.0 \%$ yaitu 3.2. Sedangkan untuk nilai rata rata aroma tepung terendah terdapat pada sampel $60^{\circ} \mathrm{C} 1.0 \%$ yaitu 2.7. Keempat sampel tepung kulit singkong ini memilki aroma agak khas singkong. Panelis tidak menemukan aroma yang signifikan antar sampel, hal ini dikarenakan aroma pada tepung kulit singkong yang mirip dan tidak jauh berbeda. Berikut nilai rata-rata panelis terhadap tekstur tepung kulit singkong tertinggi terdapat pada 
sampel $50^{\circ} \mathrm{C} 1.0 \%$ yaitu 3.9 , dengan tekstur Halus. Sedangkan untuk nilai rata rata tekstur tepung terendah terdapat pada sampel $60^{\circ} \mathrm{C} 1.0 \%$ yaitu 3.1, dengan tekstur agak halus. Semakin rendah suhu perendaman yang digunakan maka semakin mendekati tekstur yang sangat halus seperti tepung biasanya. Nilai rata-rata panelis terhadap rasa tepung kulit singkong tertinggi terdapat pada sampel $60^{\circ} \mathrm{C} 2.5 \%$ yaitu 3.1 , dengan rasa agak khas singkong. Nilai rata rata rasa tepung terendah terdapat pada sampel $60^{\circ} \mathrm{C} 1.0 \%$ yaitu 2.3 , dimana berdasarkan keterangan kuisioner sampel ini memiliki rasa khas tepung biasa.

Semakin tinggi konsentrasi perendaman yang digunakan maka semakin mendekati rasa khas singkong pada tepung kulit singkong. Sedangkan untuk penerimaan keseluruhan atau kesukaan dilakukan dengan uji hedonic, hasilnya . Nilai rata-rata kesukaan panelis terhadap tepung kulit singkong tertinggi terdapat pada sampel $50^{\circ} \mathrm{C} 1.0 \%$ yaitu 3.8 , panelis suka dengan produk tepung kulit singkong. Nilai rata rata kesukaan panelis terhadap tepung terendah terdapat pada sampel $60^{\circ} \mathrm{C} 1.0 \%$ yaitu 3.1, panelis agak suka dengan produk tepung kulit singkong. Semakin rendah suhu perendaman yang digunakan maka semakin panelis akan semakin suka dengan produk tepung kulit singkong yang dihasilkan.

\section{Kesimpulan}

sebagai berikut

Kesimpulan dari hasil penelitian ini adalah

1. Suhu dan konsentrasi starter yang digunakan saat perendaman berpengaruh nyata terhadap kadar air, kadar abu, kadar protein, kadar $\mathrm{HCN}$, derajat putih dan sifat fisik tepung kulit singkong (organoleptik). Hasil analisis kimia tepung kulit singkong yaitu kadar air berkisar antara 2,00-6,67\%, kadar abu berkisar antara 1,04-1,94\%, kadar protein berkisar antara 2,30-3,33\%, kadar HCN berkisar antara 14,0736-35,3928 $\mathrm{mg} / \mathrm{Kg}$, derajat putih sekitar $62,67-67,02 \%$, sedangkan analisis organoleptik setiap sampel diperoleh hasil yang berbeda-beda.

2. Hasil tepung kulit singkong terbaik berdasarkan uji analisis kimia dan uji organoleptik terbaik diperoleh perlakuan terbaik yaitu pada pada perendaman dengan suhu $50^{\circ} \mathrm{C}$ dan konsentrasi starter sebanyak $1,0 \%$ atau pada sampel $50^{\circ} \mathrm{C} 1,0 \%$. Dengan kadar air sebesar 2,00\%, kadar abu sebesar $1,94 \%$, kadar protein sebesar 2,52\%, kadar HCN sebesar $35,3928 \mathrm{mg} / \mathrm{Kg}$, derajat putih sebesar $67,02 \%$.

\section{Daftar Pustaka}

[1] Agbor, E.T. and Mbome, I.L. 2006. "The Effect of Processing Technique in Reducing Cyanogen Levels During The Production of Some Cameroonian Cassava Food. Journal of Food Composition and Analysis", 19(4), pp.354 - 363.
[2] AOAC. 1995. "Official Methods of Analysis of Association of Official Analytical Chemist”. AOAC International. Virginia USA. (diakses pada tanggal 20 Januari 2019)

[3] Apriyantono dkk. 1989. Analisis Pangan. Bogor: Departemen Pendidikan dan Kebudayaan Direktorat Jenderal Pendidikan Tinggi Pusat Antar Universitas Pangan dan Gizi IPB. (diakses pada tanggal 3 November 2018)

[4] Ariyantoro, A.R. dkk. 2016. "Karakteristik Fisikokimia Tepung Koro Pedang (Canavalia ensiformis) Termodifikasi Dengan Variasi Konsentrasi Asam Laktat Dan Lama Perendaman”. Jurnal Agritech Vol. 36, No. 1.

[5] Arvika, A.S. 2017. "Penambahan Tepung Kulit Singkong (Manihot Utilisma) pada Pembuatan Bika Ambon. Tugas Akhir. Politeknik Negeri Balikpapan.

[6] Badan Standarisasi Nasional. 1992 . SNI 01- 2997 - 1992. Tepung Kulit Singkong. Jakarta.

[7] Badan Standarisasi Nasional. 1992 . SNI 01- 2891 - 1992. Cara Uji Makanan dan Minuman. Jakarta.

[8] Cheng GW dan Breen PJ. 1991. Activity of phenylalanine ammonia-lyase (PAL) and concentrations of anthocyanins and phenolics in developing strawberry fruit. Jurnal American Society Horticultural Science 116(5): 865-869.

[9] Coursey, D.G. 1973. Cassava as food: Toxicity and of Interdisplinary. Workshop, London, England.

[10] Djaafar, T. F., Rahayu, S., dan Gardjito, M. 2009. Pengaruh Blanching dan Waktu Perendaman dalam Larutan Kapur terhadap Kandungan Racun pada Umbi dan Ceriping Gadung.Jurnal Teknologi Pertanian Yogyakarta.

[11] Depkes RI, (1999).Badan Pengawas Perdagangan Berjangka Komoditi, Peristilahan Dalam Perdagangan Berjangka Komoditi, Jakarta.

[12] Direktorat Gizi. 1981. Komposisi Kimia Ubi Jalar. Direktorat Gizi Departemen Kesehatan RI. Jakarta.

[13] Fitriani, N.D dan Wikanastri Hersoelistyorini. 2012. Subtitusi Tepung Kulit Singkong terhadap Daya Kembang, Kadar Serat, dan Organoleptik pada Chiffon cake. Jurnal Pangan dan Gizi Vol .03 No. 05.

[14] Hermansyah. 2012. Penuntun Praktikum Biokimia. Inderalaya: MIPA UNSRI.

[15] Khasanah, Suci Robbiatul. 2017. "Pengaruh Variasi Waktu dan Suhu Pengeringan Tepung Labu Kuning (Cucurbita Moschata) Terhadap Kandungan Betakaroten". Tugas Akhir. Politeknik TEDC Bandung

[16] Lusi, Marlina.: 'Pengaruh kondisi operasi pada pemurnian garam dapur dengan penambahan soda kaustik'. Jurnal Poltek TEDC Vol. 9 No. 1 Januari 2015, pp 20-25. 